\title{
Breeding and genetics of two new amphiploid Festulolium synthetics with improved yield and digestibility
}

\author{
J. BAERT*, K. VAN LAERE, C. VAN WAES, A. GHESQUIERE, and J. APER \\ Flanders Research Institute for Agriculture, Fisheries and Food, Plant Sciences Unit, 9090 Melle, Belgium
}

\begin{abstract}
In order to introduce drought tolerance and improved cell wall digestibility from fescue in fodder ryegrasses, we developed two amphiploid Festulolium synthetics. One is a synthetic composed of three selected drought tolerant F1 hybrid genotypes from a cross between tetraploid Lolium multiflorum and hexaploid Festuca arundinacea, further on called LMFA. The other is a synthetic composed of five selected genotypes with soft leaves from a cross between tetraploid Lolium perenne and tetraploid Festuca pratensis, further on called LPFP. We produced seeds in polycrosses of two generations of both amphiploids, i.e., syn 1 and syn2, and tested them in plot trials to determine the yield and fodder quality. The syn1 of both Festulolium populations had a higher annual dry matter yield than the reference Lolium cultivars and Festulolium cultivars composed of the same parental species. However, the syn2 of LMFA did not show an improved drought tolerance during a dry growing season compared to other Festulolium cultivars, and the seed yield of LMFA syn1 was low and dropped extremely in syn2. The number of chromosomes of LMFA also decreased gradually from F1 to syn2, and there was a clear shift in chromosome composition towards the Lolium genome. The LPFP synthetic performed better. Although the sugar content was significantly lower than the sugar content of the perennial ryegrass cultivars, organic matter digestibility (OMD) of LPFP was as high as OMD of the tetraploid perennial ryegrass cultivars. The cell wall digestibility (NDFD) of LPFP was significantly higher than the NDFD of both parental species and higher than the NDFD of all tested Festulolium cultivars. The seed yield of LPFP was the same in syn1 and syn2. The chromosome number remained on average the same and no clear shift of the chromosome composition to one of the composing genomes was observed. Overall, chromosome analysis revealed a high number of aneuploidy in syn1 and syn2 generations of both LMFA and LPFP and a lot of variation in number of Lolium, Festuca and recombinant chromosomes, and in the Lolium:Festuca genome ratio was observed among different genotypes of the same population. Therefore, selection for genotypes with a more stable genome composition will be a prerequisite for a sufficient seed yield and a broader exploitation of these new Festulolium synthetics.
\end{abstract}

Additional key words: Festuca arundinacea, genomic in situ hybridization, forage yield, Lolium multiflorum, seed yield, GISH.

\section{Introduction}

Perennial ryegrass (Lolium perenne L.; Lp) and Italian ryegrass (Lolium multiflorum Lam.; Lm) are the most common fodder grasses in NW Europe. They have a high yield and a good digestibility. Due to global warming, dry spells during summer will more often occur in this temperate maritime region. Drought periods cause severe reductions in dry matter yield of ryegrass (Aper et al. 2013). Tall fescue (Festuca arundinacea Schreb.; $\mathrm{Fa}$ ) is more drought tolerant than Lolium because of its higher root biomass (Cougnon et al. 2016). However, the digestibility of the organic matter of tall fescue is at least $5 \%$ points lower compared to Lp (Cougnon et al. 2013).
In recent years the digestibility of perennial ryegrass was improved by breeding for a higher sugar content, though a high sugar content in the grass may cause rumen acidosis. Therefore it might be better to improve the digestibility of the cell wall in order to further improve the organic matter digestibility. Meadow fescue (Festuca pratensis Huds., Fp) has a higher cell wall digestibility than diploid perennial ryegrass (Baert et al. 2013). Interspecific hybridization of ryegrass with tall fescue or meadow fescue may improve yield, especially under drought conditions, and cell wall digestibility of the ryegrass. It is known that the genome composition in Festulolium is not stable. Kopecky et al. (2006) performed genomic in situ hybridisation (GISH) on over 600 Festulolium plants and revealed a large range

Submitted 15 June 2020, last revision 17 September 2020, accepted 18 September 2020.

Abbreviations: DM - dry matter; Fa - Festuca arundinacea; Fp - Festuca pratensis; GISH - genomic in situ hybridisation; Lm - Lolium multiflorum; Lp - Lolium perenne; NDFD - neutral detergent fibre digestibility; OMD - organic matter digestibility; WSC - water soluble carbohydrates.

Acknowledgements: We would like to thank Magali Losschaert, Veerle Buyssens, and Katrien Liebaut for their assistance in the GISH analysis.

* Corresponding author; e-mail: joost.baert@ilvo.vlaanderen.be 
of variation in Lolium:Festuca genome composition and intergenomic recombination. The result is a highly variable progeny with every single plant having a unique chromosome constitution (Kopecky et al. 2017). Due to genomic instability, the seed yield of amphiploid Festulolium cultivars may be low (Ghesquière et al. 2010).

Here, we bred two novel amphiploid Festulolium populations, one from a $\mathrm{Lm} \times \mathrm{Fa}$ cross and one from a $\mathrm{Lp} \times \mathrm{Fp}$ cross and studied their agricultural value and genomic composition.

\section{Materials and methods}

Interspecific crosses, evaluation of $\mathrm{F} 1$ progeny plants, and composition of polycrosses: In 2011 we made interspecific hand crosses between Lolium and Festuca. Tetraploid genotypes of Lolium perenne (Lp) cultivars Meltador and Maurizio were crossed with tetraploid genotypes of Festuca pratensis (Fp), obtained after tetraploidization of the diploid cultivar Merifest by colchicine treatment. Tetraploid genotypes of Lolium multiflorum $(\mathrm{Lm}) \mathrm{cv}$. Livictory were crossed with hexaploid genotypes of Festuca arundinacea $(\mathrm{Fa}) \mathrm{cv}$. Barolex. The F1 plants together with their parents were visually scored for spring and summer growth, crown rust resistance, leaf softness and winter hardiness in the field in 2012 and for drought tolerance in a rain-out shelter in 2013. From the cross $\mathrm{Lm} \times \mathrm{Fa}$ we selected $3 \mathrm{~F} 1$ genotypes with a high score for drought tolerance. From the $\mathrm{Lp} \times \mathrm{Fp}$ cross we selected 5 F1 genotypes with a high score for leaf softness.

All selected plants had average to good scores for growth, rust resistance, and winter hardiness (Table 1). With these two groups we carried out two polycrosses in 2013. The synthetic population originating from the Lm $\times \mathrm{Fa} \mathrm{F} 1$ hybrids is called further on LMFA and from the Lp $\times$ Fp F1 hybrids LPFP.
Forage yield, feed quality, and seed yield of new amphiploid synthetics: The syn 1 seeds of the polycrosses were sown in a plot $\left(8 \mathrm{~m}^{2}\right)$ trial on a sandy loam soil in Belgium, Merelbeke $\left(50^{\circ} 58^{\prime} 55^{\prime \prime} \mathrm{N}, 3^{\circ} 46^{\prime} 18^{\prime \prime} \mathrm{E}\right)$ in April 2014 together with the Festulolium cv. Festilo, a registered cultivar in Belgium resulting from a cross between tetraploid Festuca pratensis and tetraploid Lolium hybridum (Lh), and other reference cultivars of Lp cvs. Abermagic and Aberbite, of Lm cvs. Podium and Caballo, of Fp cv. Merifest, of Fa cv. Kora, and of Festulolium amphiploids Lp $\times$ Fp cvs. Prior and Fabel, of Lm $\times$ Fa cvs. Becva and Lofa, and Lm $\times$ Fp cvs. Aberniche and Achilles. These reference cultivars were also included in the Eucarpia multisite Festulolium trial (Kopecky et al. 2018). Three replicates of each entry were arranged in a randomized complete block design. The plots were mown and sampled at 4 cuts in 2015 and 5 cuts in 2016 to determine the dry matter (DM) yield and the quality parameters: organic matter digestibility (OMD), water soluble saccharide content (WSC), and neutral detergent fibre digestibility (NDFD) by near infrared reflectance spectroscopy (NIRS). Therefore, the samples were scanned on a FOSS XDS monochromator instrument with ISIscan v. 2.85.1 software (Foss, Hilleroed, Denmark). The calibration development was executed with WINSI v. 4.9.0. software using modified partial least squares regression (Shenk and Westerhaus 1991). The reference methods for the NIRS calibrations were: the pepsin cellulase method described by De Boever et al. (1988) for OMD, a iodometric titration for WSC (Wiseman et al. 1960) and the determination of cell wall digestibility described by Goering and Van Soest (1970) for NDFD. The data were analysed by ANOVA using the Statistica (v.13.5.0.17, Tibco, Palo Alto, CA, USA) software.

At the end of the second harvest year of the plot trial, 1000 plants of each of the two syn 1 populations LMFA and LPFP were randomly sampled in the plots and multiplied

Table 1. Characteristics of parents and selected F1 amphiploid genotypes used in polycrosses (scores 1-9; $9=$ best).

\begin{tabular}{|c|c|c|c|c|c|c|c|c|c|c|c|}
\hline $\begin{array}{l}\text { Parent/ } \\
\text { F1 }\end{array}$ & $\begin{array}{l}\text { Species }+ \\
\text { cultivar }\end{array}$ & Polyploidy & Headings & Inflorescence & Spring growth & $\begin{array}{l}\text { Summer } \\
\text { growth }\end{array}$ & Rust resist. & $\begin{array}{l}\text { Winter } \\
\text { hard. }\end{array}$ & $\begin{array}{l}\text { Leaf } \\
\text { soften. }\end{array}$ & $\begin{array}{l}\text { Drought } \\
\text { toler. }\end{array}$ & Polycross \\
\hline \multirow[t]{5}{*}{$\mathrm{P}$} & Lm Livictory & $4 x$ & $30 \mathrm{Apr}$ & ear & 7 & 2 & 4 & 5 & 7 & 2 & \\
\hline & Lp1 Maurizio & $4 x$ & 12 May & ear & 6 & 6 & 7 & 5 & 9 & 2 & \\
\hline & Lp2 Meltador & $4 x$ & 9 Jun & ear & 5 & 5 & 4 & 5 & 7 & 4 & \\
\hline & Fa Barolex & $6 x$ & $25 \mathrm{Apr}$ & panicle & 6 & 6 & 3 & 7 & 3 & 7 & \\
\hline & Fp Merifest $4 x$ & $4 x$ & 12 May & panicle & 5 & 7 & 7 & 4 & 7 & 5 & \\
\hline \multirow[t]{8}{*}{$\mathrm{F} 1$} & $\mathrm{Lm} \times \mathrm{Fa}$ & $5 x$ & $28 \mathrm{Apr}$ & panicle & 8 & 8 & 8 & 7 & 7 & 7 & LMFA \\
\hline & $\mathrm{Lm} \times \mathrm{Fa}$ & $5 x$ & 5 May & panicle & 8 & 8 & 8 & 7 & 7 & 9 & \\
\hline & $\mathrm{Lm} \times \mathrm{Fa}$ & $5 x$ & 5 May & panicle & 8 & 8 & 8 & 5 & 7 & 9 & \\
\hline & $\mathrm{Lp} 1 \times \mathrm{Fp}$ & $4 x$ & 12 May & ear & 8 & 5 & 5 & 7 & 7 & 5 & LPFP \\
\hline & $\mathrm{Lp} 1 \times \mathrm{Fp}$ & $4 x$ & 12 May & ear & 6 & 6 & 6 & 7 & 9 & 5 & \\
\hline & $\mathrm{Lp} 1 \times \mathrm{Fp}$ & $4 x$ & 8 May & ear & 8 & 6 & 6 & 9 & 9 & 8 & \\
\hline & $\mathrm{Lp} 1 \times \mathrm{Fp}$ & $4 x$ & 22 May & ear & 7 & 8 & 7 & 7 & 9 & 3 & \\
\hline & $\mathrm{Lp} 2 \times \mathrm{Fp}$ & $4 x$ & 22 May & ear & 7 & 7 & 6 & 7 & 9 & 3 & \\
\hline
\end{tabular}


to syn2 seeds in 2017. Seed yield (kilogram of germinating seeds per square meter) of the synthetics was determined on the isolation plots of the polycrosses and multiplications. The seed yield of tetraploid Lp and Lm synthetics and of the Festulolium cv. Festilo was measured on adjacent isolation plots as a reference. In May 2018 the syn 2 seeds of the new synthetics LMFA and LPFP were sown in a plot trial following a randomized complete block design on a sandy loam soil in Merelbeke together with Festulolium reference cvs. Aberniche, Achilles, and Festilo. The plots were mown and sampled at 5 cuts in 2019 to determine the DM yield and the OMD, WSC, and NDFD, according the methods described above. In 2019 spring and summer were dry in Merelbeke. The rainfall in April/May and July/August was 54 and $79 \mathrm{~mm}$, respectively, compared to $103 \mathrm{~mm}$ and $141 \mathrm{~mm}$ in ten years before.

Determination of the genome stability of the Festulolium synthetics: We performed genomic in situ hybridisation (GISH) on at least 7 genotypes of the syn 1 and syn 2 of the two Festulolium synthetics LMFA and LPFP and of the syn 3 and syn 4 of the cv. Festilo for comparison. For this we made chromosome spreads from young apical root tips according to the "SteamDrop" method (Kirov et al. 2014). Root tips were pre-treated with ice-cold water and fixated in a ethanol:acetic acid 3:1 (v/v) solution at room temperature for $45 \mathrm{~min}$. Cell suspensions were made from the fixated root tips after digestion with $0.6 \%$ enzyme mixture $[0.6 \%(\mathrm{~m} / \mathrm{v})$ cellulase Onozuka RS (Duchefa Biochemie, Haarlem, The Netherlands), and $0.6 \%(\mathrm{~m} / \mathrm{v})$ pectolyase Y-23 (Duchefa Biochemie] during $105 \mathrm{~min}$ at $37^{\circ} \mathrm{C}$. Chromosome spreads were prepared with $1: 1(\mathrm{v} / \mathrm{v})$ ethanol: acetic acid as fixative 1 and $0: 1$ (v/v) ethanol:acetic acid as fixative 2. Total genomic DNA of Lm, Lp, Fa, and Fp was extracted from $100 \mathrm{mg}$ of fresh young leaves using the cetyltrimethylammonium bromide (CTAB) protocol (Doyle and Doyle 1987). The genomic DNA was labelled as a probe by biotin-16-dUTP or digoxigenin by nick translation after sonication $(40 \mathrm{~V}, 15 \mathrm{~s})$. Block DNA was obtained by sonication ( $40 \mathrm{~V}, 4 \mathrm{~min} 30 \mathrm{~s}$ ) of genomic DNA to fragments of 100 - $300 \mathrm{bp}$. Denaturation, hybridization, and detection was performed as described in Van Laere et al. (2010) with a probe:block ratio of 1:20. Stringency wash was done by washing the slides twice in $2 \times$ saline sodium citrate (SSC) at room temterature for $15 \mathrm{~min}$, twice in $0.1 \times \mathrm{SSC}$ at $50{ }^{\circ} \mathrm{C}$ for $7 \mathrm{~min}$ and twice in $2 \times$ $\mathrm{SSC}$ at $50{ }^{\circ} \mathrm{C}$ for $5 \mathrm{~min}$ to RT. Biotin and digoxigenin labelled probes were detected with streptavidin-Cy3 (Sigma-Aldrich, St. Louis, USA) and anti-dig-FITC (Roche, Mannheim, Germany). The chromosomes were counterstained with $0.1 \mathrm{mg} \mathrm{cm} \mathrm{cm}^{-3}$ DAPI and mounted in Vectashield $(1: 100 ; \mathrm{v} / \mathrm{v})$. Chromosome analysis was done with an AxioImager M2 (Zeiss, Zaventem, Belgium) fluorescence microscope equipped with an Axiocam $M R m$ camera (Zeiss). Images were captured by $Z E N$ software (Zeiss). Analysis of hybridization signals was carried out on at least 5 well-spread metaphases of each genotype. The number of Lolium, Festuca, and recombined chromosomes and the proportion of the Lolium and Festuca genome in the Festulolium synthetics were analysed using DrawID (Kirov et al. 2017). As a control for cross hybridisation between Festuca and Lolium, GISH was performed on Fp chromosome spreads using the Lm probe and on $\mathrm{Lm}$ and $\mathrm{Lp}$ chromosome spreads using the Fp probe.

\section{Results}

The dry mass yield of syn 1 of LMFA was intermediate between the DM yield of both parental species but

Table 2. Total annual dry matter (DM) yield, organic matter digestibility (OMD), sugar content (WSC), and NDF digestibility (NDFD) of two new Festulolium synthetics (syn1) compared to cultivars of their parental species and commercial Festulolium cultivars measured in 2015 and 2016. Means followed by different letters are significantly different at a $5 \%$ level (Duncan's multiple range test).

\begin{tabular}{|c|c|c|c|c|c|c|}
\hline Cultivar & Species & Ploidy & $\begin{array}{l}\text { DM yield } \\
{\left[\mathrm{kg} \mathrm{m}^{-2} \text { year }^{-1}\right]}\end{array}$ & OMD [\%] & WSC $[\%$ of DM] & NDFD [\%] \\
\hline Podium & $\mathrm{Lm}$ & $2 x$ & $1.56 \mathrm{bc}$ & $72.2 \mathrm{fg}$ & $15.2 \mathrm{cde}$ & $66.2 \mathrm{e}$ \\
\hline Caballo & $\mathrm{Lm}$ & $4 x$ & $1.48 \mathrm{de}$ & $72.8 \mathrm{efg}$ & 15.6 bcde & $65.7 \mathrm{e}$ \\
\hline Kora & $\mathrm{Fa}$ & $6 x$ & $1.75 \mathrm{a}$ & $69.9 \mathrm{~g}$ & $14.4 \mathrm{de}$ & $70.1 \mathrm{~cd}$ \\
\hline Becva & $\mathrm{Lm} \times \mathrm{Fa}$ & $4 x$ & $1.34 \mathrm{f}$ & $76.1 \mathrm{~cd}$ & 15.9 bcde & $69.7 \mathrm{~cd}$ \\
\hline Lofa & $\mathrm{Lm} \times \mathrm{Fa}$ & $4 x$ & $1.38 \mathrm{f}$ & 75.7 cde & 14.9 cde & $69.3 \mathrm{~d}$ \\
\hline LMFA syn1 & $\mathrm{Lm} \times \mathrm{Fa}$ & $5 x$ & $1.59 \mathrm{bc}$ & $74.2 \mathrm{def}$ & $15.1 \mathrm{cde}$ & $70.1 \mathrm{~cd}$ \\
\hline Abermagic & $\mathrm{Lp}$ & $2 x$ & $1.52 \mathrm{~cd}$ & $79.7 \mathrm{ab}$ & $20.1 \mathrm{a}$ & $70.2 \mathrm{~cd}$ \\
\hline Aberbite & $\mathrm{Lp}$ & $4 x$ & $1.43 \mathrm{ef}$ & $81.0 \mathrm{a}$ & $19.8 \mathrm{a}$ & $71.9 \mathrm{bc}$ \\
\hline Merifest & $\mathrm{Fp}$ & $2 x$ & $1.35 \mathrm{f}$ & $78.5 \mathrm{abc}$ & $13.6 \mathrm{e}$ & $73.1 \mathrm{ab}$ \\
\hline Fabel & $\mathrm{Lp} \times \mathrm{Fp}$ & $4 x$ & $1.43 \mathrm{ef}$ & $79.7 \mathrm{ab}$ & $17.0 \mathrm{bc}$ & $73.0 \mathrm{~b}$ \\
\hline Prior & $\mathrm{Lp} \times \mathrm{Fp}$ & $4 x$ & $1.35 \mathrm{f}$ & $79.3 \mathrm{ab}$ & $17.7 \mathrm{~b}$ & $70.4 \mathrm{~cd}$ \\
\hline LPFP syn1 & $\mathrm{Lp} \times \mathrm{Fp}$ & $4 x$ & $1.59 \mathrm{bc}$ & $80.8 \mathrm{a}$ & 15.7 bcde & $75.4 \mathrm{a}$ \\
\hline Aberniche & $\mathrm{Lm} \times \mathrm{Fp}$ & $4 x$ & $1.58 \mathrm{bc}$ & 75.4 cde & $17.6 \mathrm{~b}$ & $68.8 \mathrm{~d}$ \\
\hline Achilles & $\mathrm{Lm} \times \mathrm{Fp}$ & $4 x$ & $1.58 \mathrm{bc}$ & $77.3 \mathrm{bcd}$ & 15.4 bcde & $72.2 \mathrm{bc}$ \\
\hline Festilo & $\mathrm{Lh} \times \mathrm{Fp}$ & $4 x$ & $1.62 \mathrm{~b}$ & $78.6 \mathrm{abc}$ & $16.4 \mathrm{bcd}$ & $74.1 \mathrm{ab}$ \\
\hline
\end{tabular}


Table 3. Total annual dry matter (DM) yield, organic matter digestibility (OMD), sugar content (WSC) and NDF digestibility (NDFD) of two new Festulolium synthetics (syn2) compared to commercial Festulolium cultivars in the dry year 2019. Means followed by different letters are significantly different at a $5 \%$ level (Duncan's multiple range test).

\begin{tabular}{llllll}
\hline Cultivar & Hybrid type & DM yield $\left[\mathrm{kg} \mathrm{m}^{-2}\right.$ year $\left.^{-1}\right]$ & OMD [\%] & WSC [\% of DM] & NDFD [\%] \\
\hline Aberniche & Lm $\times$ Fp & $1.55 \mathrm{a}$ & $75.7 \mathrm{~b}$ & $14.6 \mathrm{a}$ & $73.6 \mathrm{~b}$ \\
Achilles & Lm $\times$ Fp & $1.46 \mathrm{ab}$ & $76.1 \mathrm{~b}$ & $12.4 \mathrm{~b}$ & $75.7 \mathrm{~b}$ \\
Festilo & Lh $\times$ Fp & $1.46 \mathrm{ab}$ & $78.7 \mathrm{ab}$ & $13.6 \mathrm{ab}$ & $77.4 \mathrm{ab}$ \\
LMFA syn2 & Lm $\times$ Fa & $1.48 \mathrm{ab}$ & $77.1 \mathrm{~b}$ & $14.3 \mathrm{ab}$ & $74.7 \mathrm{~b}$ \\
LPFP syn2 & Lp 3 Fp & $1.40 \mathrm{~b}$ & $83.3 \mathrm{a}$ & $13.9 \mathrm{ab}$ & $80.4 \mathrm{a}$ \\
\hline
\end{tabular}

significantly higher than the cvs. Becva and Lofa with the same parental composition (Table 2). LMFA syn1 had a similar DM yield as the Festulolium reference cvs. Aberniche, Achilles, and Festilo. The digestibility of LMFA syn1 was slightly superior to cvs. of the

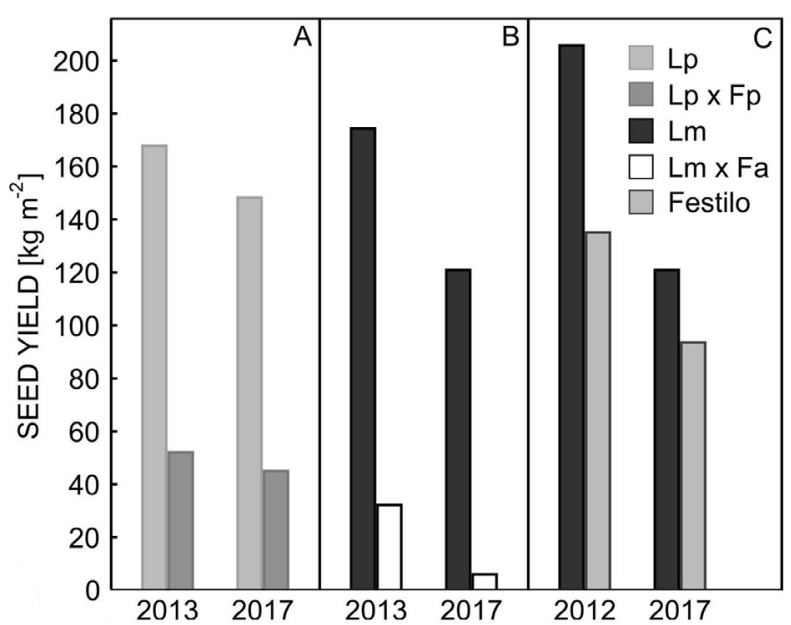

Fig. 1. The seed yield of syn1 (2013) and syn2 (2017) of Lolium perenne $(\mathrm{Lp}) \times$ Festuca pratensis $(\mathrm{Fp})$ and Lolium multiflorum $(\mathrm{Lm}) \times$ Festuca arundinacea $(\mathrm{Fa})$ amphiploid Festulolium compared to the seed yield of tetraploid synthetics of $\mathrm{Lp}(A)$ and $\operatorname{Lm}(B)$ in the same harvest years, and syn3 (2012) and syn4 (2017) of Festulolium cv. Festilo (C) (unreplicated plots on the same fields). parental species because of the combination of a similar WSC content to the Lolium parent and a similar NDFD to the Festuca component. Although LMFA syn1 was composed of drought tolerant components, the DM yield of the syn2 was not superior to the Festulolium reference cultivars in the dry season of 2019 (Table 3). On the contrary, cv. Aberniche outyielded LMFA.

The dry matter yield of the syn 1 of LPFP was superior to the DM yield of cvs. of the parental species and significantly higher than the cvs. Fabel and Prior with the same parental composition (Table 2). The DM yield of LPFP syn1 was very similar to the yield of the Festulolium reference cvs. Aberniche, Achilles, and Festilo. The digestibility of LPFP was as high as the OMD of the tetraploid perennial ryegrass cultivars but the WSC content was significantly lower than the WSC content of the perennial ryegrass cultivars. The NDF digestibility was significantly higher compared to both parental species and higher than all Festulolium cultivars. In 2019, the total DM yield of the syn2 of LPFP was lower than the DM yield of the Festulolium reference cultivars but the digestibility was significantly higher due to the significantly higher cell wall digestibility (Table 3).

The seed yield of both new amphiploid synthetics was much lower than the seed yield of the Lolium species (Fig. 1). The seed yield of LPFP remained rather stable in the two consecutive generations at about $30 \%$ relative to the perennial ryegrass reference. The seed yield of LMFA dropped extremely from syn1 to syn2, from 18 to $5 \%$ relative to the Italian ryegrass reference. For comparison:
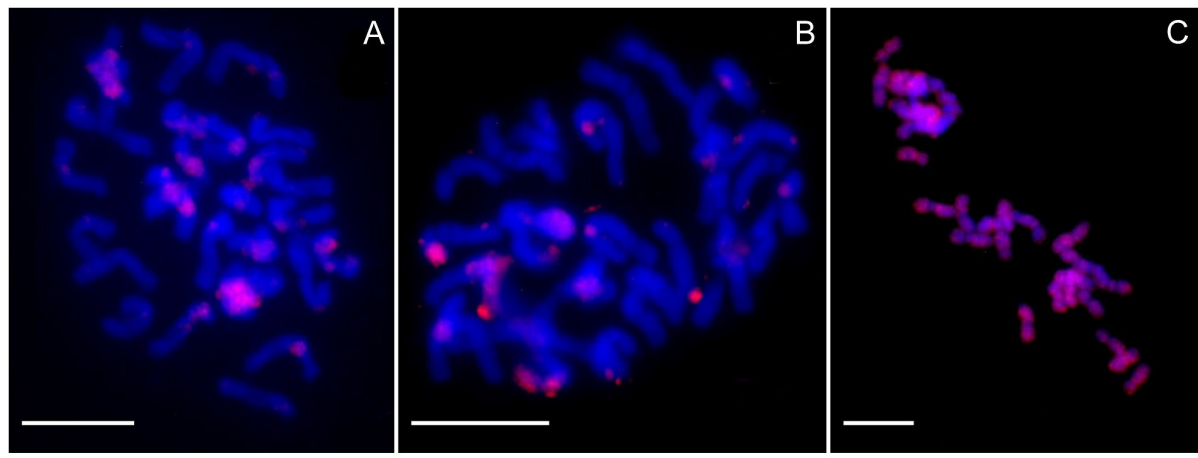

Fig. 2. Genomic in situ hybridisation of the parental species: $A$ - Fp chromosomes (blue) hybridised with an Lp probe (red). $B$ - Lm chromosomes (blue) hybridised with an Fp probe (red). C - Lp chromosomes (blue) hybridised with an Lm probe (red). Bars are $10 \mu \mathrm{m}$. 

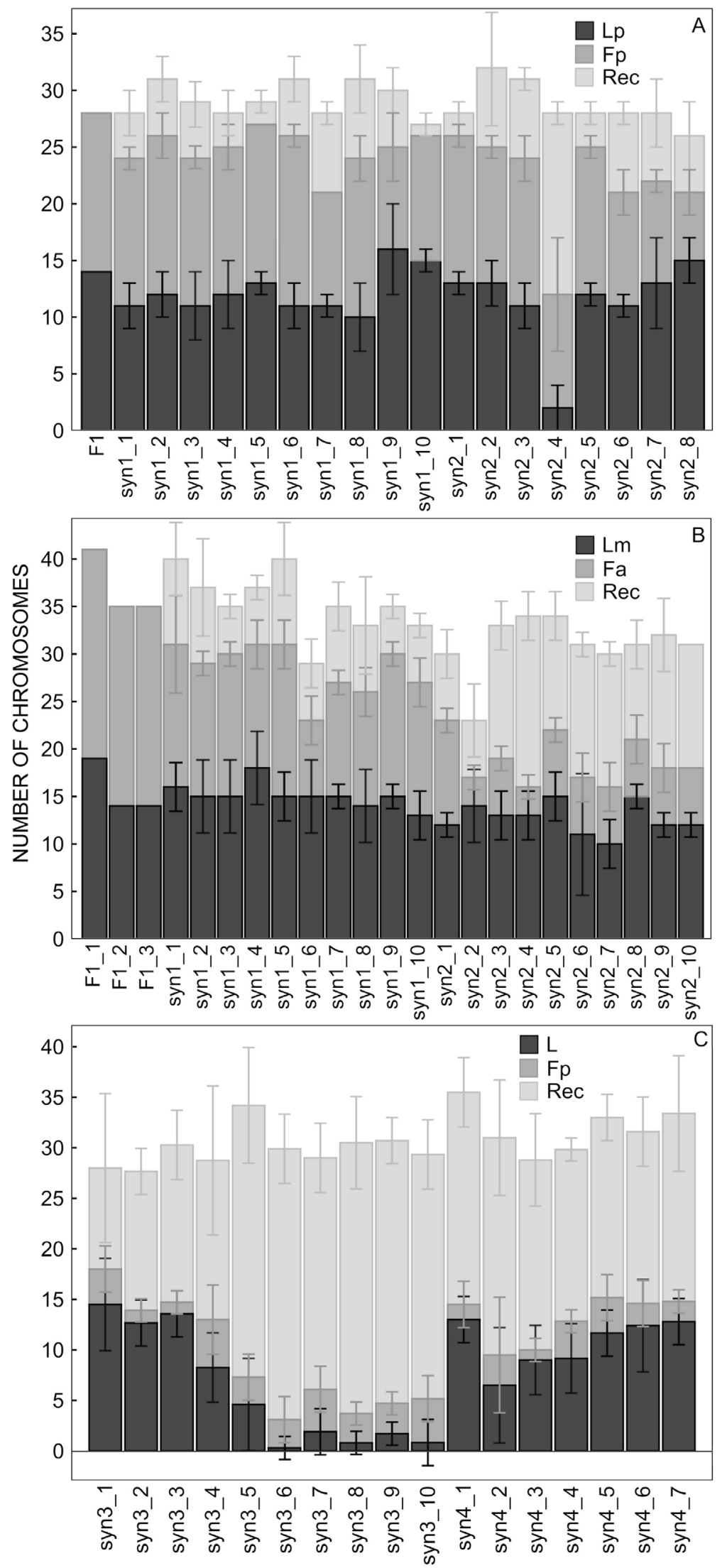

Fig. 3. Chromosome composition of $\mathrm{F} 1$, syn1, and syn2 genotypes of Lolium perenne $(\mathrm{Lp}) \times$ Festuca pratensis $(\mathrm{Fp})$ hybrids $(A)$ and Lolium multiflorum $(\mathrm{Lm}) \times$ Festuca arundinacea $(\mathrm{Fa})$ hybrids $(B)$, and of syn 3 and syn 4 genotypes of cv. Festilo $(C)$. 
the seed yield of the Lh $\times$ Fp amphiploid cv. Festilo increased from $66 \%$ in syn 3 to $77 \%$ in syn 4 relative to the Italian ryegrass reference.

First we confirmed the chromosome number of the parental species: Lp: $2 n=4 x=28$, Lm: $2 n=4 x=28$, Fp: $2 n=4 x=28$, Fa: $2 n=6 x=42$. Second, we determined the amount of cross hybridisation between Festuca and Lolium by GISH. Although Kopecky et al. (2008) reported no staining of Festuca chromosomes by a Lolium probe, we could observe that there is little $(9.68 \pm 8.66 \%)$ cross hybridisation between these 2 parental species (Fig. 2), most probably accounting for conserved repetitive sequences. $\mathrm{Lm}$ and $\mathrm{Lp}$ share $47.25 \pm 9.86 \%$ similarity (Fig. 2). However, overall, we can conclude that it will be possible to distinguish between the Festuca and Lolium parental genomes in the Festulolium amphidiploids using GISH.

For the F1 genotypes of LMFA, we could observe 35 chromosomes, which could be expected based on the chromosome numbers of the parental species. Since this odd number of chromosomes in the F1 generation, we expected chromosome instability in the further generations. The syn1 genotypes that were analysed contained between 28 and 40 chromosomes, of which
13 to $18 \mathrm{Lm}$ chromosomes, 8 to $16 \mathrm{Fa}$ chromosomes, and 5 to 9 recombinant chromosomes. Remarkably, the syn2 genotypes had only left between 23 and 34 chromosomes (Figs. $3 B$ and $4 A, B$ ), of which 10 to 15 came from $\mathrm{Lm}$, 3 to 11 from $\mathrm{Fa}$, and 6 to 18 were recombinant. Due to the GISH procedure, we could observe that sometimes chromosomes break down at the centromeres, which makes it not always possible to count the exact number of chromosomes, explaining the chromosome amount variation within one genotype.

The Lm:Fa genome ratio in the F1 genotypes is expected to be 40:60, which is confirmed by our GISH analysis (Table 4). Determination of the Lm:Fa genome ratio revealed for most syn 1 genotypes a genome composition showing a slight shift towards the Lm genome (Table 4). In the syn 2 generation this shift towards the Lm genome is more clear and present for all tested syn2 genotypes (Table 4). The genotype syn2_2 for example has about $75 \% \mathrm{Lm}$ genome and only about $25 \% \mathrm{Fa}$ genome left. This genotype also has only 23 chromosomes, so most probably this genotype just lost many of the Fa chromosomes.

The F1 genotype of LPFP contained 28 chromosomes $(2 n=4 x=28)$, i.e., $14 \mathrm{Lp}$ and $14 \mathrm{Fp}$ chromosomes. Since both parental species are tetraploids with a similar

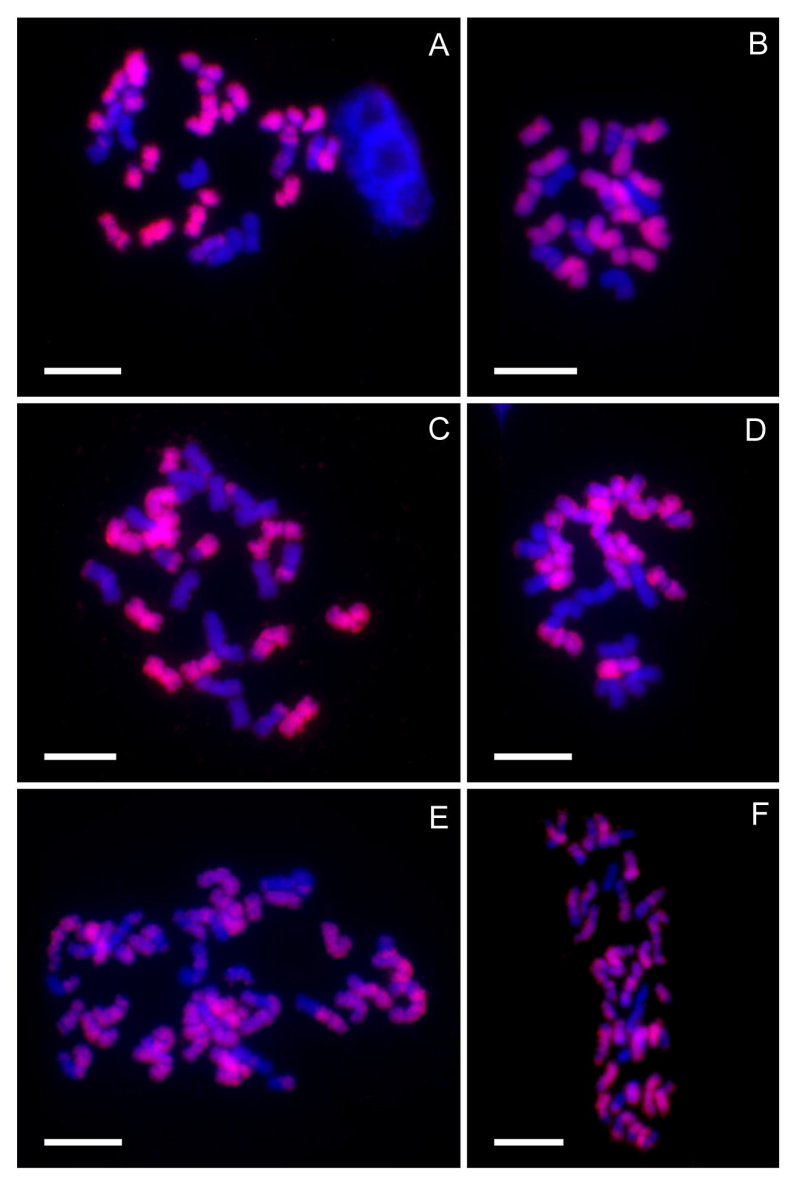

Fig. 4. A,B - genomic in situ hybridisation of syn1 Lolium multiflorum $(\mathrm{Lm}) \times$ Festuca arundinacea $(\mathrm{Fa})(\mathrm{syn} 16, A)$ and syn2 Lm $\times$ Fa (syn2_2, B); red - Lm probe, blue - Fa block. C,D - GISH analysis of syn1 Lolium perenne (Lp) $\times$ Festuca pratensis (Fp) (syn1_7,C) and syn $2 \mathrm{Lp} \times \mathrm{Fp}(\operatorname{syn} 2 \quad 8, D)$; red $-\mathrm{Lp}$ probe, blue - Fp block. E,F - GISH analysis of syn3 cv. Festilo (syn3 5, E) and syn4 cv. Festilo (syn4_5, F); red - Lolium (L) probe, blue - Fp block. Bars are $10 \mu \mathrm{m}$. 
Table 4. The Lolium multiflorum (Lm) : Festuca arundinacea $(\mathrm{Fa})$ genome ratio in the F1, syn1, and syn2 genotypes of the Lm $\times$ Fa hybrid.

\begin{tabular}{llllll}
\hline Genotype & Lm genome [\%] & Fa genome [\%] & Genotype & Lm genome [\%] & Fa genome [\%] \\
\hline F1_1 & $41.04 \pm 1.04$ & $58.96 \pm 1.12$ & Syn2_1 & $50.91 \pm 1.34$ & $49.09 \pm 1.34$ \\
F1_2 & $40.17 \pm 1.92$ & $59.83 \pm 1.89$ & Syn2_2 & $75.33 \pm 6.23$ & $24.67 \pm 6.23$ \\
Syn1_1 & $45.78 \pm 3.82$ & $54.22 \pm 3.82$ & Syn2_3 & $56.61 \pm 9.82$ & $43.40 \pm 3.61$ \\
Syn1_2 & $48.07 \pm 3.36$ & $51.93 \pm 3.36$ & Syn2_4 & $63.72 \pm 5.24$ & $36.28 \pm 5.24$ \\
Syn1_3 & $47.35 \pm 4.42$ & $52.65 \pm 4.42$ & Syn2_5 & $56.34 \pm 2.61$ & $43.66 \pm 2.61$ \\
Syn1_4 & $54.81 \pm 2.91$ & $45.19 \pm 2.91$ & Syn2_6 & $51.00 \pm 6.33$ & $49.01 \pm 6.33$ \\
Syn1_5 & $44.70 \pm 6.85$ & $55.31 \pm 6.85$ & Syn2_7 & $56.86 \pm 5.09$ & $43.14 \pm 5.09$ \\
Syn1_6 & $59.49 \pm 10.78$ & $40.51 \pm 10.78$ & Syn2_8 & $62.26 \pm 4.82$ & $37.74 \pm 4.82$ \\
Syn1_7 & $50.30 \pm 2.51$ & $49.70 \pm 2.51$ & Syn2_9 & $63.06 \pm 3.81$ & $36.95 \pm 3.81$ \\
Syn1_8 & $47.11 \pm 3.70$ & $52.89 \pm 3.70$ & Syn2_10 & $58.01 \pm 0.47$ & $42.00 \pm 0.47$ \\
Syn1_9 & $51.24 \pm 1.10$ & $48.76 \pm 1.10$ & & & \\
Syn1_10 & $47.93 \pm 4.20$ & $52.07 \pm 4.20$ & & & \\
\hline
\end{tabular}

Table 5. The Lolium perenne (Lp) : Festuca pratensis (Fp) genome ratio in the F1, syn1, and syn2 Lp $\times$ Fp amphidiploid genotypes.

\begin{tabular}{llllll}
\hline Genotype & Lp genome [\%] & Fp genome [\%] & Genotype & Lp genome [\%] & Fp genome [\%] \\
\hline F1 & $48.99 \pm 0.83$ & $51.02 \pm 0.83$ & Syn2_1 & $47.47 \pm 0.92$ & $52.53 \pm 0.92$ \\
Syn1_1 & $44.23 \pm 4.42$ & $55.77 \pm 4.42$ & Syn2_2 & $47.63 \pm 10.20$ & $52.37 \pm 10.20$ \\
Syn1_2 & $43.92 \pm 3.87$ & $56.03 \pm 3.87$ & Syn2_3 & $45.78 \pm 4.41$ & $54.22 \pm 4.41$ \\
Syn1_3 & $43.78 \pm 4.42$ & $56.48 \pm 4.20$ & Syn2_4 & $27.70 \pm 6.94$ & $72.30 \pm 6.94$ \\
Syn1_4 & $48.62 \pm 7.65$ & $51.35 \pm 7.65$ & Syn2_5 & $45.27 \pm 2.96$ & $54.73 \pm 2.96$ \\
Syn1_5 & $47.91 \pm 1.03$ & $52.09 \pm 1.03$ & Syn2_6 & $50.53 \pm 3.74$ & $49.47 \pm 3.74$ \\
Syn1_6 & $38.70 \pm 3.99$ & $61.32 \pm 3.95$ & Syn2_7 & $56.39 \pm 5.99$ & $43.62 \pm 5.99$ \\
Syn1_7 & $48.36 \pm 0.69$ & $51.64 \pm 0.69$ & Syn2_8 & $65.37 \pm 0.48$ & $34.63 \pm 0.48$ \\
Syn1_8 & $41.69 \pm 8.56$ & $58.31 \pm 8.56$ & & & \\
Syn1_9 & $60.74 \pm 7.96$ & $39.26 \pm 7.96$ & & & \\
Syn1_10 & $55.48 \pm 2.89$ & $44.52 \pm 2.89$ & & & \\
\hline
\end{tabular}

Table 6. The Lolium (L) : Festuca pratensis (Fp) genome ratio in the syn3 and syn4 Festulolium cv. Festilo.

\begin{tabular}{llllll}
\hline Genotype & L genome [\%] & Fp genome [\%] & Genotype & L genome [\%] & Fp genome [\%] \\
\hline Syn3_1 & $71.80 \pm 1.29$ & $28.20 \pm 1.26$ & Syn4_1 & $72.26 \pm 8.35$ & $27.74 \pm 8.35$ \\
Syn3_2 & $78.12 \pm 2.65$ & $21.88 \pm 2.35$ & Syn4_2 & $66.58 \pm 16.42$ & $33.42 \pm 16.42$ \\
Syn3_3 & $77.88 \pm 4.88$ & $21.70 \pm 5.53$ & Syn4_3 & $66.48 \pm 6.23$ & $33.52 \pm 6.23$ \\
Syn3_4 & $56.20 \pm 4.90$ & $43.80 \pm 4.90$ & Syn4_4 & $63.03 \pm 4.84$ & $36.97 \pm 4.83$ \\
Syn3_5 & $56.38 \pm 6.96$ & $43.63 \pm 6.96$ & Syn4_5 & $68.24 \pm 7.23$ & $31.77 \pm 7.53$ \\
Syn3_6 & $46.47 \pm 6.05$ & $53.53 \pm 6.05$ & Syn4_6 & $71.35 \pm 4.36$ & $28.65 \pm 4.36$ \\
Syn3_7 & $49.97 \pm 7.84$ & $50.03 \pm 7.84$ & Syn4_7 & $67.77 \pm 4.95$ & $32.23 \pm 4.95$ \\
Syn3_8 & $48.91 \pm 4.98$ & $51.09 \pm 4.98$ & & & \\
Syn3_9 & $47.12 \pm 8.35$ & $52.88 \pm 8.35$ & & & \\
Syn3_10 & $46.92 \pm 6.87$ & $53.08 \pm 6.87$ & & & \\
\hline
\end{tabular}

chromosome amount, we could expect to observe $2 n=4 x=28$ chromosomes in further generations. Indeed, half of the 10 syn 1 and 8 syn2 genotypes that were analysed by GISH contained 28 chromosomes, but a high number of aneuploidy was also observed (Figs. $3 A$ and $4 C, D)$. Also here it has to be taken into account that due to the breakdown of some chromosomes at the centromeres during the GISH procedure, it is not always possible to count the exact number of chromosomes of each genotype. High frequencies of aneuploidy were also seen in Festulolium studies before (Kopecky et al. 2017), e.g., in Fp $\times$ Lp hybrids (Majka et al. 2019). In our syn1 and 
syn2 genotypes, there was a large variation of Lp, Fp, and recombinant chromosomes. In the syn 1 genotypes between 10 and $16 \mathrm{Lp}$ and between 9 and $15 \mathrm{Fp}$ chromosomes were observed. In addition, between 2 and 7 chromosomes were recombinant (Figs. $3 A$ and $4 C, D$ ). The $\mathrm{Lp}$ :Fp genome ratio is expected to be 50:50. By calculating the percentage Lp and Fp genome present in the F1, syn1, and syn2 genotypes, we could conclude that this Lp:Fp genome ratio is quite stable, with some exceptions (Table 5). In most genotypes the percentage $\mathrm{Lp}$ and $\mathrm{Fp}$ is about $50 \%$. The genotypes syn1_6 and syn2_4 showed a shift towards the Fp genome, while the genotypes syn1_9 and syn2_8 had a shift towards the Lp genome (Table 5).

As a comparison, we also did GISH analysis on syn3 and syn 4 genotypes of the commercial tetraploid Lh $\times$ Fp Festulolium cv. Festilo. As a probe, we used a mix of Lp and Lm labelled genomic DNA. We could observe a high number of recombinant chromosomes both in syn 3 and syn 4 genotypes. The syn 3 genotypes had between 0 and 15 Lolium chromosomes, between 1 and 5 Fp chromosomes, and between 10 and 27 recombinant chromosomes (Figs. $3 C$ and $4 E, F$ ). Most syn3 genotypes had a rather stable genome composition, only 3 syn 3 genotypes showed a clear shift towards the Lolium genome (Table 6). Syn4 genotypes had 7 to 13 Lolium chromosomes, 1 to $4 \mathrm{Fp}$ chromosomes, and 17 to 22 recombinant chromosomes. However, due to the breakage of some chromosomes during the GISH procedure, the exact number of chromosomes is difficult to determine per genotype. In syn 4 generation the shift towards the Lolium genome was much more pronounced in all genotypes (Table 6).

\section{Discussion}

By crossing Lm and $\mathrm{Fa}$ we aimed at breeding a drought tolerant synthetic Festulolium cultivar. The F1 genotypes composing the LMFA synthetic population were at least as drought tolerant as the tall fescue parent. Although the syn 1 of LMFA was higher yielding than $\mathrm{Lm} \times$ Fa reference cultivars and had a similar yield as $\mathrm{Lm} \times$ Fp cultivars, the syn2 showed no DM yield improvement compared to the $\mathrm{Lm} \times \mathrm{Fp}$ Festulolium cultivars during the dry growing season of 2019. A possible reason might be the reduction of the Fa genome in LMFA from F1 to syn2 resulting in less drought tolerance. Syn2 seeds were harvested on syn1 plants sampled in plots at the end of two management years and might be affected by a kind of natural selection. In switch grass and timothy natural selection for survivorship increased biomass yield (Casler and Smart 2013, Reheul et al. 2003). Here this effect was not observed. On the one hand, the sampling might have caused a shift towards the more persistent component, i.e. tall fescue. On the other hand, syn1 genotypes with a larger Lolium/Festuca ratio might have been advantaged directly after sowing because of their faster establishment. In mixtures with perennial ryegrass the content of $\mathrm{Fa}$ was lower than the sown proportion in the first year after sowing but increased over the years and dominated after 3 years (Cougnon et al.
2013). Also the seed yield of LMFA was very low. This could be expected when producing seeds from pentaploid F1 genotypes. The seed yield dropped from syn1 to syn2. This coincided with a decrease of the chromosome number and a clear shift of the genome composition towards the Lolium genome. We can expect a continued shift towards the Lolium genome in further generations of the $\mathrm{Lm} \times$ Fa amphiploid selection. Kopecky et al. (2018) found in cvs. Becva and Lofa, all developed from $\mathrm{Lm} \times \mathrm{Fa}$ hybrids followed by backcrossing onto tetraploid Lm, a large proportion of plants with no evidence for the presence of any Festuca chromatin. This indicated the rapid elimination of the Festuca chromatin and a preferential transmission of Lolium chromosomes or advantage gained by genotypes having predominance of the Lolium genome complement.

The breeding goal of the Lp $\times$ Fp cross was to develop a highly digestible Festulolium cultivar. For that the LPFP synthetic was really successful with a significantly better digestibility than all Festulolium cultivars in all growing seasons. It was as digestible as the tetraploid perennial ryegrass cv. Aberbite. The high digestibility of Aberbite was due to its high sugar content. The high digestibility of LPFP was due to its outstanding cell wall digestibility, contributed by the Fp genome. The DM yield of the new LPFP synthetic was significantly better than the DM yield of existing Lp $\times$ Fp cultivars. Also the seed yield of syn 1 and syn 2 of LPFP was stable. The chromosome number remained the same in the successive generations of this Lp $\times$ Fp amphiploid and GISH revealed no clear shift to one of the composing genomes. However the seed yield was lower than the seed yield of the $\mathrm{Lh} \times \mathrm{Fp} \mathrm{cv}$. Festilo containing Lm in its genomic composition. This might be due to a closer relationship between Fp and Lm than between Fp and Lp resulting in a more stable genomic composition because of more frequent homoeologous recombination between Fp and Lm than between Fp and Lp (Kopecky et al. 2018).

Festilo is a registered cultivar listed in Belgium and commercially available. Yet it shows some instability in genome composition. There is still a shift towards the Lolium genome from syn3 to syn4. GISH analysis by Kopecky et al. (2017) of 3 consecutive generations ( $1^{\text {st }}$ generation the one for cultivar registration) of 3 Festulolium cultivars revealed that the gradual shift towards Lolium is observed in the early generations and reaches a plateau in later generations where the proportions of parental genomes become stabilized. This was also seen by Zwierzykowsky et al. (2006, 2011), where a gradual shift towards Lolium was observed from F2 to F7 and then a genome stabilisation between F7 and F8. So it will be important to evaluate our 2 selected amphidiploid synthetics over further generations. Stabilization of the genome composition will be a prerequisite for a stable and sufficient seed yield and a broader exploitation of the Festulolium synthetics. Backcrossing to Lolium may improve seed yield but reduces the Festuca genome in the genomic composition of the Festulolium. There is a lot of variation in seed yield among single genotypes of the new Festulolium synthetics. We will try to improve the seed 
yield by selecting single tetraploid genotypes with a high seed yield.

\section{References}

Aper, J., Ghesquiere, A., Cougnon, M., Baert, J.: Drought effect on yield of perennial ryegrass. - In: Sokolovic, D., Huyghe, C., Radovic, J. (ed.): Quantitave Traits Breeding for Multifunctional Grasslands and Turf. Pp. 367-372. Springer, Dordrecht 2013.

Baert, J., Ghesquiere, A., Van Waes, C.: Variation of cell wall digestibility in fodder grasses and a perennial ryegrass (Lolium perenne L.) breeding pool. - In: Sokolovic, D., Huyghe, C., Radovic, J. (ed.): Quantitave Traits Breeding for Multifunctional Grasslands and Turf. Pp. 261-265. Springer, Dordrecht 2013.

Casler, M.D., Smart, A.J.: Plant mortality and natural selection may increase biomass yield in switchgrass swards. - Crop Sci. 53: 500-506, 2013.

Cougnon, M., Baert, J., Van Waes, C., Reheul, D.: Performance and quality of tall fescue (Festuca arundinacea Schreb.) and perennial ryegrass (Lolium perenne L.) and mixtures of both species grown with or without white clover (Trifolium repens L.) under cutting management. - Grass Forage Sc. 69: 666677, 2013.

Cougnon, M., De Swaef, T., Lootens, P., Baert, J., De Frenne, P., Shahidi, R., Roldán-Ruiz, I., Reheul, D.: In situ quantification of forage grass root biomass, distribution and diameter classes under two $\mathrm{N}$ fertilisation rates. - Plant Soil 411: 409-422, 2016.

De Boever, J.L., Cottyn, B.G., Andries, J.I., Buysse, F.X., Vanacker, J.M.: The use of a cellulase technique to predict digestibility, metabolizable and net energy of forages. - Anim. Feed Sci. Technol. 19: 247-260, 1988.

Doyle, J.J., Doyle, J.L.: A rapid DNA isolation procedure for small quantities of fresh leaf tissue. - Phytochem. Bull. 19: 11-15, 1987.

Ghesquière, M., Humphreys, M., Zwierzykowski, Z.: Festulolium. - In: Boller B., Posselt U., Veronesi F. (ed.): Handbook of Plant Breeding. Fodder Crops and Amenity Grasses. Pp. 293-316. Springer, Dordrecht 2010.

Goering, H.K., Van Soest, P.J.: Forage Fiber Analyses (Apparatus, Reagents, Procedures, and Some Applications). (Agriculture Handbook No. 379). - ARSUSDA, Washington 1970.

Kirov, I., Divashuk, M., Van Laere, K., Soloviev, A., Khrustaleva, L.: An easy "SteamDrop" method for high quality plant chromosome preparation. - Mol. Cytogenet. 7: 21, 2014.

Kirov, I., Khrustaleva, L., Van Laere, K., Soloviev, A., Meeus, S., Romanov, D., Fesenko, I.: DRAWID: user-friendly java software for chromosome measurements and idiogram drawing. - CompCytogen 11: 747-757, 2017.

Kopecky, D., Baert, J., Barth, S., Bartos, J., Cernoch, V., Dolezel, J., Grogan, D., Harper, J., Humphreys, M., Ksiazczyk, T., Ostrem, L., Paszkowski, E., Sokolovic, D., Zwierzykowski, Z., Ghesquiere, M.: Genotyping of Festulolium cultivars involved in Eucarpia multi-site trial using DArT markers and GISH. - In: Brazauskas, G., Statkeviciute, G., Jonaviciene, K. (ed.): Breeding Grasses and Protein Crops in the Era of Genomics. Pp. 155-159. Springer, Dordrecht 2018.

Kopecky, D., Loureiro, J., Zwierzykowsky, Z., Ghesquière, M., Dolezel, J.: Genome constitution and evolution in Lolium $\times$ Festuca hybrid cultivars (Festulolium). - Theor. appl. Genet. 113: 731-742, 2006.

Kopecky, D., Lukaszewski, A.J., Dolezel, J.: Cytogenetics of Festulolium (Festuca $\times$ Lolium hybrids). - Cytogenet. Genome Res. 120: 370-383, 2008.

Kopecky, D., Simonikova, D., Ghesquière, M., Dolezel, J.: Stability of genome composition and recombination between homoeologous chromosomes in Festulolium (Festuca $\times$ Lolium) cultivars. - Cytogenet. Genome Res. 151: 106-114, 2017.

Majka, J., Bzdega, K., Janiak, A., Cwiek-Kupczynska, H., Krajewski, P., Ksiazczyk, T., Zwierzykowski, Z.: Cytogenetic and molecular genotyping in the allotetraploid Festuca pratensis $\times$ Lolium perenne hybrids. - BMC Genomics 20: 367, 2019.

Reheul, D., Baert, J., Ghesquiere, A., Waters, B.: Progress in breeding perennial fodder grasses 3. Different ways to create varieties of Phleum pratense. - Czech. J. Genet. Plant Breed. 39: 64-67, 2003.

Shenk, J.S., Westerhaus, M.O.: Population structuring of near infrared spectra and modified partial least squares regression. - Crop Sci. 31: 1548-1555, 1991.

Van Laere, K., Khrustaleva, L., Van Huylenbroeck, J., Van Bockstaele, E.: Application of GISH to characterize woody ornamental hybrids with small genomes and chromosomes. Plant Breed. 129: 442-447, 2010.

Wiseman, H.G., Mallack, J.C., Jacobson, W.C.: Determination of sugar in silages and forages. - J. Agr. Food. Chem. 8: 78-80, 1960.

Zwierzykowski, Z., Kosmala, A., Zwierzykowska, E., Jones, N., Joks, W., Bocianowski, J.: Genome balance in six successive generations of the allotetraploid Festuca pratensis $\times$ Lolium perenne. - Theor. appl. Genet. 113: 539-547, 2006.

Zwierzykowski, Z., Zwierzykowska, E., Taciak, M., Kosmala, A., Jones, R.N., Zwierzykowski, W., Książczyk, T., Krajewski, P.: Genomic structure and fertility in advanced breeding populations derived from an allotetraploid Festuca pratensis $\times$ Lolium perenne cross. - Plant Breed. 130: 476-480, 2011. 